\title{
Taste diaspora: The aesthetic and material practice of belonging
}

Journal of Material Culture 2014, Vol. 19(2) 185-208

(C) The Author(s) 2014

Reprints and permissions:

sagepub.co.uk/journalsPermissions.nav DOI: $10.1177 / 1359183514521922$

mcu.sagepub.com

\section{Özlem Savaş}

Bilkent University, Ankara, Turkey

\begin{abstract}
A particular 'Turkish taste in Vienna', which has been formed through experiences of migration from Turkey and resettlement in Vienna, serves as a significant aesthetic and social medium for constituting a collective sense of belonging. This article explores how Turkish people in Vienna constitute, perform and enunciate belongings through practices and discourses around travelling forms and spaces of material culture. Underpinned by an ethnography founded on a repertoire of Turkish objects in Vienna, this article addresses the relational constitution of a particular taste and a diasporic belonging within a specific context of displacement and relocation of both people and material objects. 'Taste diaspora' refers to a certain diasporic sphere that is formed through a collective taste in material objects and enunciated in the aesthetics of the everyday.
\end{abstract}

\section{Keywords}

Diaspora, material culture, taste, Turkish migration, Vienna

Travels of people entail travels of things. The Turkish labour migration to Vienna that began in the mid-1960s, following the bilateral guest worker agreement, has been accompanied by countless travelling objects, from the tea glasses brought to Vienna in suitcases to the gifts carried to Turkey in Mercedes cars. ${ }^{1}$ Recently, the Turkish presence in Vienna, established by institutions, businesses, and political and religious organizations has been reinforced and made manifest by everyday forms and spaces of material culture. Homes, shops, bodies and city spaces belonging to Turks are constituted and expressed as such by means of a repertoire of Turkish objects in Vienna. A particular 'Turkish taste' in

\footnotetext{
Corresponding author:

Özlem Savaş, Department of Communication and Design, Bilkent University (Illetişim ve Tasarım Bölümü Bilkent Üniversitesi), 06800 Bilkent, Ankara, Turkey.

Email: ozlems@bilkent.edu.tr
} 
everyday objects, which has been shaped by specific experiences of displacement and dwelling, serves as a significant aesthetic and social medium for building a collective sense of belonging to Vienna.

As the Turkish population in Vienna is diverse, it is impossible to assert a uniform, coherent and all-encompassing taste. ${ }^{2}$ Yet there exists a certain taste that is described as the 'typical Turkish taste in Vienna' and has significance for the constitution and representation of 'Turkish' in Vienna. This article addresses that taste and explores how a collective diasporic belonging is constituted, performed and represented through practices and discourses around travelling forms and spaces of material culture. Based on a larger ethnographic study carried out in Vienna over three years (Savaş, 2008), this article examines the relational construction of a certain diasporic sphere and a particular taste within a specific context of displacement and relocation of both people and material objects.

Although diasporic aesthetics concerning art, film, music and literature have been explored in diaspora and migration studies, material cultures and everyday aesthetics have not attracted the same amount of scholarly attention. Experiences of Turkish migrants in Western European countries have been studied in relation to media consumption (Aksoy and Robins, 2000; Ehrkamp, 2005; Kosnick, 2004), music (particularly hip hop; Kaya, 2000, 2002) and literature (Fischer and McGowan, 1996; Frölich, 1997; Horrocks, 1996). Yet with a few exceptions (Çağlar, 1995, 1997a, 2002; Ehrkamp, 2005; Ger and Østergaard, 1998), the role of material objects, consumption, taste, style and fashion in Turkish migration and resettlement has commonly been neglected.

This neglect is surprising when one recalls that material objects played a significant role in shaping migration aspirations in rural Turkey in the 1960s and 1970s. Turkish labour migration is not a conventional example of forced migration; yet migrants had a little or no choice given their unfavourable economic and social circumstances. The main motives for migration were to find jobs, attain a higher economic status and save money for a future life in Turkey. The more prosperous conditions in Western Europe were embodied in attractive objects and gifts 'made in Europe' that migrants carried to their home towns in Turkey during the summer vacations. While the most typical gifts were Marlboro cigarettes, whiskies, German chocolates, shampoos and Nivea creams, the most appreciated included clothes, watches, dolls, radios, cameras and TVs. Until the late 1980s, migrants attempted to achieve higher social positions in Turkey by means of their Mercedes cars and European objects. As Çağlar (1995, 1997a, 2002) argues, these migrants were often regarded as having economic capital but lacking the cultural and symbolic capital needed for upward social mobility. In urban Turkey, the stereotypical and humorous image of the male Turkish worker in Europe always involved a Mercedes car, a hat with a plume and a radio carried on the shoulder. However, inhabitants of rural Turkey who had not migrated yet imagined the wealthy European in a Mercedes car, with a camera or a beautiful dress and dreamed of going to the places these goods came from.

Pierre Bourdieu's (1984) book Distinction, which shows that taste is a form of power to reproduce class structure, was influential in formulating this study, which rests in its broadest sense on the idea that taste matters in the production and reproduction of social relations. Yet I also agree with Miller (1987: 158) when he criticizes Bourdieu's approach 
to material objects in Distinction (in contrast to his earlier work on the Kabyle house in Outline of a Theory of Practice, 1977) because it 'is based upon the mapping of differences between goods on differences between social groups, which ... are often treated as prior social divisions unaltered by this process of signification'. I regard taste diaspora as shaped by a mutually constitutive relationship between persons and things, in which neither is prior (Miller, 1987; Tilley, 2006). As Geismar and Horst (2004: 5-6) suggest, research engaging with materiality necessitates a relational approach, which implies 'an understanding of how categories (e.g. subject/object) or entities (e.g. person/thing) work in relation to one another to produce further sets of relationships or understandings that at their broadest might be termed "culture", "society", or "locality", Thus, this ethnographic study seeks to understand how stories of displaced people and displaced objects intertwine in the making of taste diaspora.

Studies on taste, material culture and consumption in migratory or diasporic contexts are dominated by the concept of culture, which is often employed as an ahistorical, natural and self-evident form. I attempt to move beyond both essentialist views that regard migratory or diasporic material cultures as inherited from the past and hybridization accounts that leave no room for cultural particularity other than the blending or mixture of the two presupposed cultural forms (i.e. the culture of the country of origin and the culture of the country of settlement). This study was founded on material objects and everyday practices and the discourses around them rather than on a pre-defined and self-evident community, identity or culture in order to "[draw] attention to the daily process of "making culture", rather than "having a culture"” (Baumann, 1996: 6). Thus, it allows for an understanding of the particularities of Turkish experiences of Vienna as arising from the historical, social and economic processes specific to the Turkish displacement and dwelling, which a notion of 'Turkish culture' as a self-evident category would easily mask.

During fieldwork, I observed people's relations with material objects and listened to the various narratives on migration and Turkish life in Vienna, through participant observation, in-depth interviews and general conversation. The aim of following the repertoire of Turkish objects in Vienna guided this research to a wide variety of sites: homes, shops, schools, political and religious organizations and leisure sites patronized by Turkish people, such as shopping malls, parks, picnic areas in Donauinsel and Kahlenberg, Mariahilfer Strasse (Vienna's main shopping street), Brunnenmarkt (a street market in the 16th district) and Turkish restaurants, clubs and wedding rooms. To deepen my understanding of Turkish life and self-representations, I examined local Turkish newspapers, catalogues from and advertisements for Turkish shops, internet sites providing communication and forums for Vienna's Turkish residents, and Austria's Turkish radio station, Radio Merhaba. Noticing that certain objects are significant for constituting and enunciating Turkishness in Vienna, I traced the biographies of those objects (Kopytoff, 1988), as they too have social lives (Appadurai, 1988). Since the question of displacement is central not only for the people but also the objects engaged in this research, I aimed to explore the spatial and temporal paths that led to their inclusion in the repertoire of Turkish objects in Vienna. Doing so enabled me to address the complex displacements and transformations embedded in the meanings and values of objects often viewed as 'traditional' or 'authentic'. 


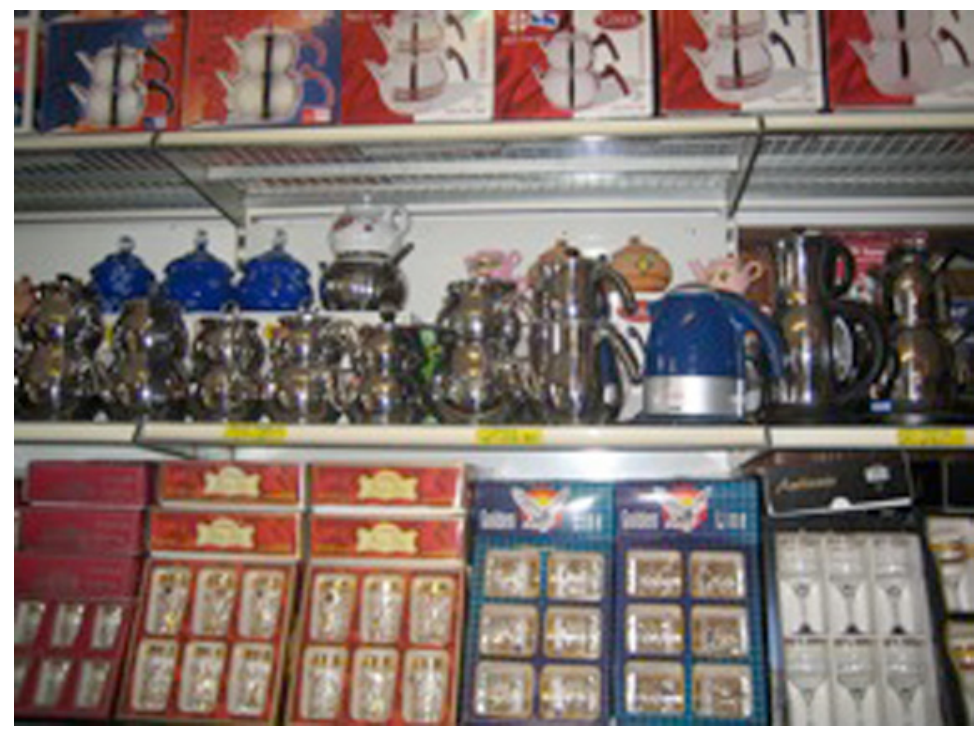

Figure I. Sets of tea glasses and teapots in a Turkish shop located in Brunnenmarkt, 16th district.

\section{Travelling people, travelling objects}

I had a very hard time my first two years in Vienna. Everything, even the lack of tea glasses was a big problem. I am addicted to tea, like many Turkish people. But I could not drink proper tea in Vienna in those years. I was told that I could not find a teapot and tea glasses in Vienna. I brought a teapot with me, but forgot the glasses. Cups or big ordinary glasses do not make me feel like drinking tea. It does not taste like tea. Anyway, after two years, I could finally go back to Turkey and of course bought tea glasses. I brought back a set of six tea glasses with their plates, spoons, everything. Believe me, my life became easier. I remember. On the evening of the day I arrived back in Vienna, I made tea and drank it with my glasses. That was the first time that I delightfully drank tea in Vienna. I felt that I was drinking tea. But also, it is strange; I felt as if I was drinking tea at home. (author's translation and italics)

This story about tea glasses was told by Veli, a 64-year-old male informant who migrated to Vienna as a guest worker in 1967. Leaving his wife in his village in northern Anatolia, he started work in a textile factory and lived in a Heim (dormitory for guest workers) provided by his employer on the outskirts of Vienna. He rarely visited the city, spending his days between Heim and factory in relative social isolation. Although his intention was to save money and return to his village, he never went back permanently. After about 10 years, his wife and two children migrated to Vienna. Nowadays, Veli and his wife have many Turkish tea glasses of various styles, which he enthusiastically showed me after telling this story. Veli explains that Turkish life in Vienna has undergone an amazing transformation, and he finds it very easy to live in Vienna today, because 'one can find any sort of tea glass in the hundreds of Turkish shops' (see Figure 1). Veli keeps the only 
tea glass remaining from the set he first brought back in his tailor's shop, believing that it brings good luck and embodies his success in Vienna.

Can objects lessen feelings of loneliness, loss, estrangement and isolation? It has been argued that possessions embedded with memories play a central role in anchoring identity and the past during displacement (see, for example, Belk, 1992; Berger, 1975; Mehta and Belk, 1991; Parkin, 1999). It has also been emphasized that memory objects play a significant role in making a new home and shaping diasporic positioning (see, for example, Tolia-Kelly, 2004; Walsh, 2006). The possibility of creating a home by and in physical things (other than a house) is part of John Berger's argument on finding a home in a world of travel. His descriptions of Turkish Gastarbeitern (guest workers) living in Heimen involve feelings of alienation, rupture and loss of home, yet retain a sense of dwelling achieved by remembering through physical things of personal importance (Berger, 1975). Similarly, with regard to Primo Levi's (1987[1958]) autobiographical portrayal of Auschwitz, Parkin (1999) argues that in conditions of isolation and dispossession, people may inscribe their selfhood in concrete objects.

The lives of Turkish migrants in the 1960s and 1970s were marked by estrangement and loss of familial and social relations. Deprivation of objects central to the material habits and visual grammar of everyday life contributed to feelings of foreignness, rupture and alienation. Yet the value of objects in coping with displacement cannot be reduced to their capacity to symbolize and recall past places, lives and relations. Rather than objects embedded with personal meanings and memories, Turkish migrants transported objects needed to reconstitute domestic habits of cleaning, eating and caring for children. As key objects of a collective cultural memory and of the visual culture of the everyday, tea glasses surely recall Turkey and represent a sort of Turkishness. However, more significantly, they are incorporated into bodily actions and feelings of the everyday, through their materiality. Their lack causes the loss of physical habits of living the everyday.

The material objects that accompanied people during their travels from Turkey to Vienna provided moments of attachment to the actual space and time inhabited in an indeterminate life suspended between return and settlement, a life characterized by travels (physical and mental) to and from Turkey. It is partly the loss of objects that tells people that they live in a foreign environment, that they are displaced or even misplaced and that they are no longer at home. It is partly the absence or presence of objects that shows people where they belong. The loss of objects is the loss of home. For this reason, as will be argued below, retrieving objects has the powerful potential to reconstitute home.

\section{The mass migration of objects and the shifted belonging}

Until about the early 1990s, the Turkish experience of Vienna was largely shaped by the 'myth of return', considering life in the new setting as temporary and implying a desire to return to one's home country (Anwar, 1979). The aim of migration was to work abroad for several years to save enough money to buy land, a house or at least a tractor in one's home town and to return. Thus, strategies of belonging were directed mainly at Turkey rather than Vienna, as can be observed in the distribution of consumption expenditures. Many people spent their earnings on gifts made in Europe to achieve social recognition 


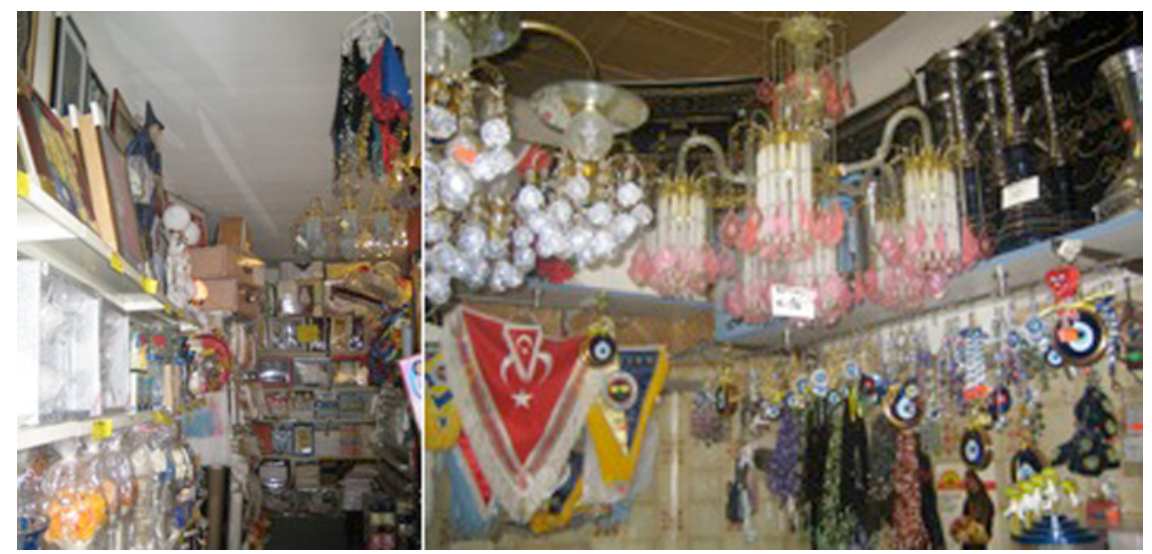

Figure 2. 'Turkish objects' sold by the two Turkish shops located in the 10th district (left) and the 16th district (right).

'back home' and on buying and decorating houses in Turkey, while living with secondhand furniture and the barest necessities in Vienna.

Recently, as many of my informants explained, the majority of Turkish people have realized that they will never permanently return to Turkey. Kallcl (staying for good) is one of the most significant words in the Turkish vocabulary in Vienna. My informants use this word to describe permanent residence in Vienna, in phrases such as 'Biz Viyana'da kalıcıyı' ('We are kalıcı in Vienna'), and 'Sen kalıcı misin?' ('Are you kalıct?'). The myth of return began to dissipate in the mid-1990s and people's tendency to save money or invest in a life in Turkey began to be transformed into spending money on their life in Vienna. ${ }^{3}$ The widespread establishment of Turkish shops has matched this transformation in consumption attitudes. Today, Vienna hosts a wide variety of Turkish shops clustered mainly in the 10th and 16th districts (see Figure 2), where most of the city's Turkish population lives. These shops sell clothes, home textiles, kitchen utensils, CDs and DVDs, and various decorative objects imported from Turkey or Berlin (which could be considered the capital city for the Turkish inhabitants of Western Europe), such as copper plates calligraphed with Qur'anic verses, replicas of the Kaaba at Mecca, amulets, plastic flowers, Turkish flags, pennants of Turkish soccer teams, emblems of the Ottoman Empire, paintings and pictures of Turkey, and porcelain objects, clocks, vases and candles. The establishment of furniture shops, in particular, following the realization of being kallcl, contributed much to the creation of permanent homes in Vienna. Hane Mobilya (mobilya meaning furniture), the first Turkish furniture shop in Vienna, bases its marketing strategy on the end of the myth of return:

Hane Mobilya is a Turkish firm that was established in Vienna in 1999 and has represented the furniture of Turkey for five years. Turkish people in Europe have invested in Turkey for years and tried to decorate their homes in Turkey in the best way, believing that they will have a better and more comfortable life in those homes after returning to Turkey. Today, our people who live here answer to the question of 'whether to stay in Europe or to return' by saying 'it is difficult 
to return'. Millions of people have stayed here. Let's decorate our homes where we spend our lives with the comfortable and beautiful furniture of Turkey, along with our hearts. We live once. Our time is precious. As you are kalıcı here, so are we. (author's translation: available at: www.hanemobilya.at, accessed 5 May 2008)

The decision to live in Vienna permanently does not imply a rupture with Turkey. On the contrary, it is largely shaped by the foundation of transnational relations with Turkey, especially the ones that take place in the domain of material culture. The establishment of Turkish shops has promoted or justified the decision to settle for good. In this sense, the mass migration of Turkish objects to Vienna has facilitated the end of the myth of return. Similar to Veli's association of the availability of tea glasses with an easier life, many of my informants who migrated in the 1960s and 1970s relate today's more comfortable, less estranged life in Vienna to the physical presence of Turkish objects, voicing comments similar to the following:

When we came to Vienna there was not a single Turkish shop. God, the life was too difficult back then. Buses and trains were filled with things we were carrying from Turkey. Today, it is very easy to live in Vienna. Whatever exists in Turkey is available also in Vienna.

The simultaneous and interrelated processes of the end of the myth of return and the growth of Turkish shops have launched a new stage in the Turkish experience of Vienna. It is no longer characterized mainly by travels to and from Turkey, but by a collective dwelling that expresses itself in many forms, including the visual and material cultures of the everyday. Today, Turkish people no longer meet at the Südbahnhof (the South Station train terminus) on Sundays to greet newcomers, not only because trains no longer carry hundreds of new migrants from Turkey, but also because there are other 'Turkish places' to meet in Vienna. Such places figure highly in constituting a collective sense of belonging in Vienna, which is perfectly expressed by an oft-repeated phrase: 'We have constructed a vatan [home, homeland] here.'

In her ethnography on Italian migrants in Britain, Fortier (2000) explores how some physical spaces serve as belongings, which refers both to 'possessions' and inclusion, since they are at once appropriated as Italian possessions and employed as 'terrains of identity'. Likewise, I regard the forms and spaces of Turkish material culture as belongings that serve as terrains of a collective sense of belonging once they have been appropriated as part of Turkishness in Vienna (see Figure 3). Some neighbourhoods - such as the 10th, 16th and part of the 20th districts - are claimed as and known to be Turkish places, having been 'resignified and reshaped according to the forms of belonging that are performed and permitted there' (Bell, 1999: 10).

One place that hosts a collective Turkish presence is Brunnenmarkt, the longest permanent street market in Europe, located in the 16th district, Ottakring. The food stalls and shops in the area are predominantly held by Turkish vendors. Turkish name plates, a variety of Turkish goods, Turkish words on the windows, posters of Turkish pop concerts and Turkish women shopping (characterized and stereotyped mainly by headscarves) reshape and mark Brunnenmarkt as a Turkish place for Turkish and non-Turkish inhabitants alike. Similarly, Ehrkamp (2005) notes the significance of shops for Turkish people 


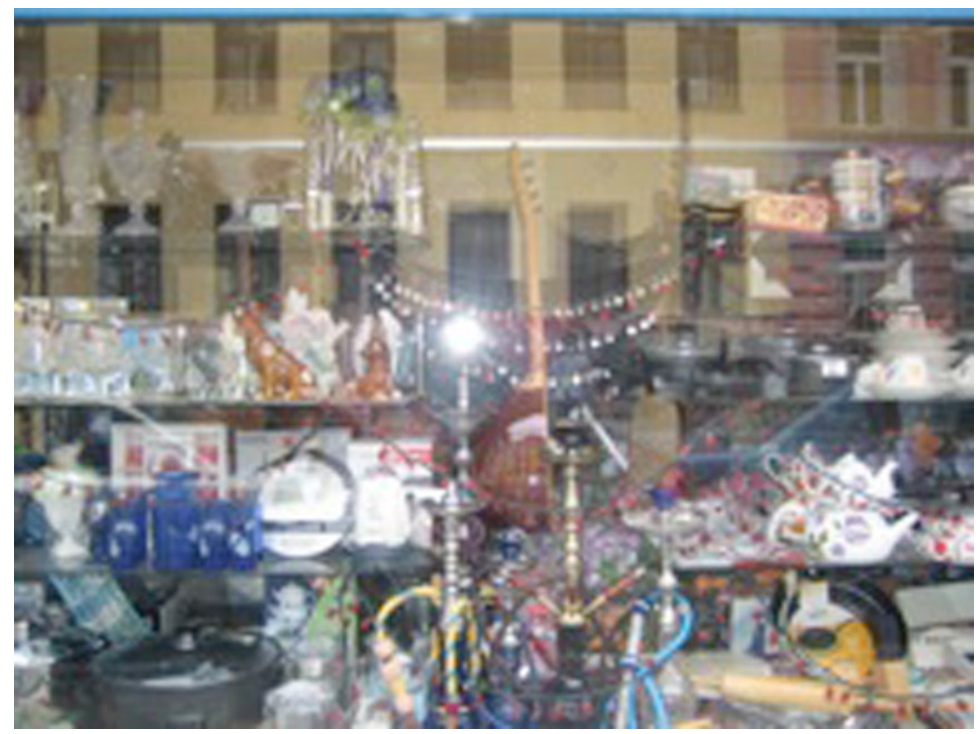

Figure 3. Visual and material marks of Turkish presence in Vienna: Window of a Turkish shop located around Brunnenmarkt, 16 th district.

attempting to make places of their own in Germany. Resignification by visual and material cultures of the everyday is imperative to creating distinctive and collective spaces that define an area of control (Beverly-McCloud, 1996; D'Alisera, 2001). Brunnenviertel, the neighbourhood around Brunnenmarkt (see Figure 4), is called 'Klein (little)-Istanbul' by Austrians and 'küçük (little) İstanbul' by Turkish people. 'Küçük İstanbul' is perhaps what inspired the FPÖ (the Freedom Party of Austria) to declare that 'Wien darf nicht Istanbul werden' ('Vienna must not become Istanbul' in its 2005 election campaign. By contrast, for Turkish inhabitants and visitors, Brunnenmarkt represents a victory of controlling a space, encapsulated by a phrase I heard many times during my visits: 'This is our place!' As Westwood (1995: 200) argues with regard to South Asian youth in Leicester, 'defence of locale', the politics of controlling a space and claiming it as one's own, is 'fundamental to a sense of belonging and to the creation and sustenance of diasporic identities'.

To sum up, Turkish people have gradually become more oriented to the particular life and community they have formed in Vienna than to their places of origin in Turkey, which long served as the idea of home and the central ground of belonging. In a similar observation about German Turks, White (1997) argues that they have begun to regard their community as the centre, by turning away from institutions in Turkey and developing their own institutions in Germany. Pointing to the concept of the 'shifting centre', Mandel $(1990,1996)$ argues that the Kreuzberg neighbourhood in Berlin has become the new orienting centre for German Turks. I consider the prevalent forms and spaces of Turkish material culture in Vienna as vital to the shift in the ground of belonging and to the transformation from migrant status to diasporic resettlement. Material objects, 


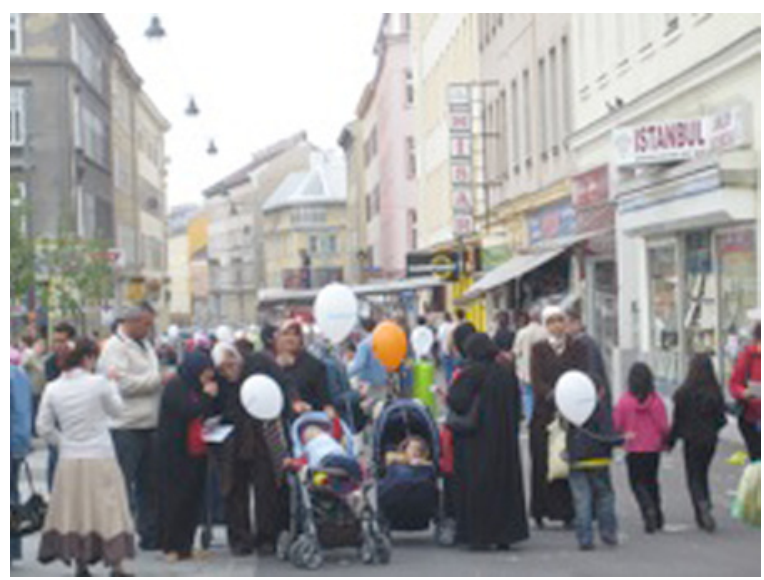

Figure 4. Brunnenmarkt, 16 th district.

particularly through their lack or presence, have shaped perceptions of Vienna and Turkey, as home or non-home, as centre or periphery. The repertoire of Turkish objects in Vienna powerfully recontextualizes Vienna as home.

\section{The collective 'Turkish taste': Dwelling and belonging through material culture}

The shift in the ground of belonging by means of moving objects is what inspired me to formulate Turkish dwelling in Vienna as a 'taste diaspora'. 'Diaspora' had previously been used to specifically describe 'the exile of the Jews from their historic homeland and their dispersion throughout many lands' (Safran, 1991: 83). Today, as the extent and variety of displacements proliferate, diaspora is used to refer to the historical and transnational formations in process (Werbner, 2004) that have arisen from dispersals of expatriates, immigrants, refugees, guest-workers, ethnic communities and so on (Safran, 1991; Tölölyan, 1996). The concept of diaspora also refers to the formation of identities and cultures through displacement, travel and movement, challenging the assumption that people are 'naturally' bonded to lands (Chambers, 1994; Clifford, 1997; Gupta and Ferguson, 1992; Said, 1980), and implies the impossibility of a stable home in a 'world of movement' (Rapport and Dawson, 1998). On the other hand, the inevitability of the desire for a home (Martin and Mohanty, 1986; Pratt, 1984) lies at the heart of diasporic formations and communities. Diaspora does not imply only travel and movement but, more powerfully, 'dwelling, maintaining communities, having collective homes away from home' (Clifford, 1994: 317).

The recent emphasis on everyday practices and performances as crucial to strategies for and politics of belonging reveal the role of taste and material culture. For instance, national projects and citizenship have been explored in relation to production and consumption of material objects (Auslander, 1996, 2001; Edensor, 2002; Foster, 1999). In her work on the meaning of furniture in Parisians' lives from the mid-17th to the early 
20th centuries, Auslander $(1996,2001)$ explores how the creation of a shared aesthetic of the everyday in terms of a 'national taste' allowed the inclusion of people in the national project of France. She focuses on taste in order to 'grasp the manifestations of the very large and abstract structures and transformations of the world within the small details of life' (Auslander, 1996: 4).

Within Turkish experiences of Vienna, desires and strategies for belonging have powerfully been embedded in everyday practices and discourses around forms and spaces of material culture. Taste diaspora is the relocation and rearticulation of travelling people and travelling objects in a specific locale. This diasporic sphere constituted from within material cultures of the everyday is not the same diasporic form as that shaped by other media, such as religious and political organizations. Werbner (2002) defines diasporas as 'chaorders', that is: chaotic orders, and argues that Manchester Pakistanis form a very local community but not a single diasporic community. With a multiplicity of orientations, she argues, they form several diasporic spheres such as a religious diaspora, an aesthetic diaspora and so on. Likewise, the taste diaspora is a unique and particular diasporic sphere among others constituted by Turkish people settled in Vienna. Constituted, performed and enunciated in the aesthetics of the everyday, taste diaspora yields belongings, identities, practices and representations that are different from the ones produced by other diasporic agents like religious/political organizations and artistic works.

Certain forms of material culture occupy a significant place in the experiences of displacement from Turkey and resettlement in Vienna. They are powerfully embedded in the migration histories and strategies for belonging oriented to Turkey and Vienna. This repertoire of Turkish objects in Vienna is utilized for constituting, performing and representing Turkish and Muslim belongings. A collectively created and defended taste in everyday objects, which is often referred to as the 'typical Turkish taste in Vienna', produces and reproduces collectivity and social differentiation. For example, collectively created normative tastes in home decoration and fashion serve for imagination and materialization of social similarity and become points of reference by which group boundaries are defined and complex diasporic belongings are evaluated, contested and played out in the everyday.

Elsewhere (Savaş, 2010), I discussed how the aesthetic and material practices of making homes intertwine with processes of constituting a collective diasporic belonging. The 'typically Turkish home' (see Figure 5), achieved by a normative taste on home decoration, serves as an aesthetic and social medium by which both a coherent collectivity is imagined and objectified and social differentiations are achieved. The aesthetic discourse that produces this type of home, that is, 'indifference to aesthetics', seemingly a careless and inconspicuous way of decoration, emerged as the result of Turkish guest-worker experiences in Vienna, such as the long-lasting myth of return, the resulting unwillingness to spend money, and real or ritualistic poverty. Aesthetic conformity to the 'typically Turkish home' is defended as an everyday expression and performance of Turkishness in Vienna, not because it has some ethnic associations, but rather because it corresponds with the particular Turkish experience of migration and resettlement.

Similarly, there exists a collectively created, distinct youth fashion, which serves to express and perform being a young Turk who was born and/or grew up in Vienna. Girls 


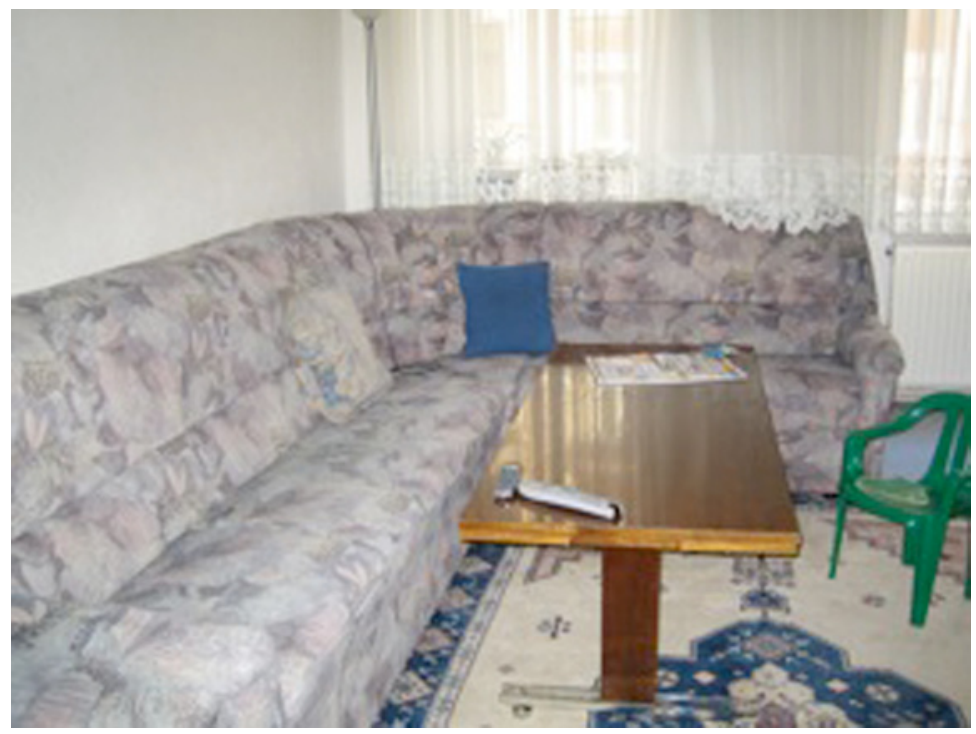

Figure 5. The living room of a home depicted as the 'typically Turkish home'.

recognize each other as Turkish by means of a certain dress style, which contrasts with those they refer to as 'bedraggled Austrian youngsters'. They wear jeans tucked into boots, ornate belts and big earrings, use black eyeliner and straighten their hair (see Figure 6). Disliking frumpy dresses in Turkish shops, veiled girls buy 'normal' clothes from regular fashion shops and convert them into a religiously acceptable form. Boys go to Turkish hairdressers to have their hair cut in the 'cool' style. They buy their jeans and sharp pointy-toed shoes from Turkey. They adore cars, but BMWs, Volkswagens, and Audis - not their fathers' Mercedes.

These distinct youth fashions are not only symbols of collectively performed identities, but also serve to realize, evaluate and defend a specific position in a complex web of diasporic relationships. Turkish youth in Vienna constantly position and re-position themselves by comparing their styles with that of diverse significant others, like Austrian youth, other migrant or diasporic youth in Vienna, Turkish youth in Turkey and in other Western European countries, especially Germany, the Netherlands and France. Yet they do not attempt to change their styles when encountering other fashions because their particular looks define and situate a collective 'we', i.e. Turkish youth born and raised in Vienna. In other words, having a particular and distinct fashion they have collectively created provides a specific position from which to speak of and for themselves within a web of complex and multiple diasporic relations.

The 'typically Turkish taste' serves as an aesthetic and social reference not only for building collectivities but also for achieving and expressing social differentiation. Through rejection of this taste, some of my informants who describe themselves as 'modern, secular, and democratic', attempt to differentiate themselves from 'typical Turkish people in Vienna' whom they regard as 'backward and ignorant'. As Wilk (1997: 183) argues, 


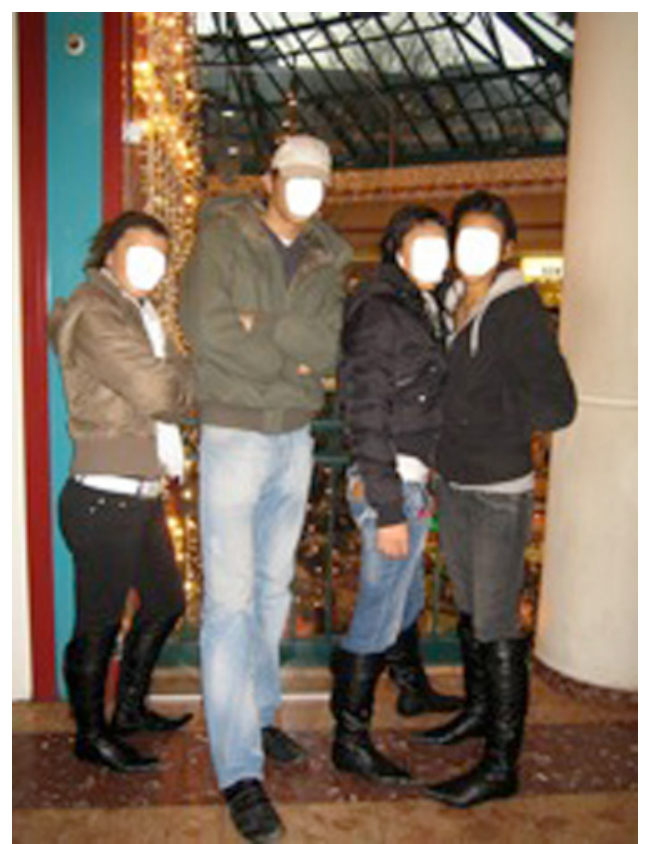

Figure 6. Turkish youngsters in a shopping mall, Lugner City.

deciding what not to consume can be more significant in forming identities than the choice of what to consume, because 'distaste and rejection is often more important than taste and consumption in making social distinctions'. Home decoration, for instance, is a highly contested practice, which reveals multiplicities and struggles within the Turkish community. Some of my informants, especially younger people, avoid objects and styles associated with the 'typically Turkish home' (see Figure 7) and claim that their tastes are similar to the 'modern taste in Turkey'. Yet their different taste in home decoration is often negatively regarded as the sign of assimilation into Austrian culture.

These taste cultures neither self-evidently exist prior to the experience of migration nor are they created through a simple mixture of two cultural forms that are supposed to be the culture of the country of origin and the culture of the country of settlement. As will be argued below, through the displaced Turkish furniture relocated to Vienna as a key object of taste diaspora, the 'Turkish taste in Vienna' has been formed within complex and specific processes that move beyond both essentialist views and hybridization accounts of diasporic aesthetics of the everyday.

\section{Displaced furniture and the local particularity of the taste diaspora}

Materially and symbolically, furniture is crucial to the taste diaspora because making a home involves both the practices of home arrangement and symbolic processes of 

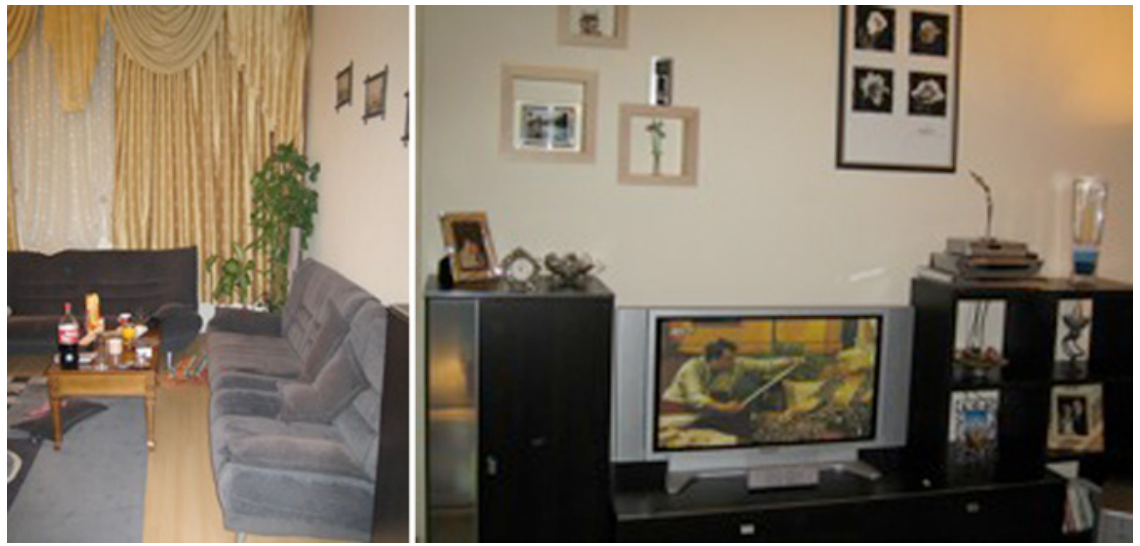

Figure 7. Living room of a young couple with a distaste for the 'typically Turkish home'.

belonging. When realizing that they would never return to Turkey, Turks in Vienna began to replace their 'aesthetically indifferent' furniture that had marked their homes as temporary and insignificant with 'beautiful Turkish furniture'. The new furniture, enthusiastically chosen from Turkish furniture shops in Vienna, objectifies the replacement of the myth of return with permanent settlement, aiding the transformation of secondary and temporary homes into main and permanent ones. Turkish furniture is at the heart of the widely reported transformation of Turkish life in Vienna, from waiting for the Sunday trains at the Südbahnhof to making a permanent home.

The recently emerging and growing Turkish furniture market in Vienna consists of five main shops: Hane Mobilya, Etsan Mobilya, Evim Mobilya, Bender Mobilya and Dekor, as well as several small-scale, family-run shops such as Wonne Mobilya. Designed and manufactured in Turkey, with a Turkish label and advertised in Turkish media, this furniture is both a concrete and a symbolic object that links Vienna to Turkey transnationally. However, this style connection with Turkey involves specific processes that have shaped the local particularity of the 'Turkish taste in Vienna': what are the specificities of engagement with the style worlds of Turkey? What kind of furniture constitutes the permanent Turkish homes made in Vienna?

Turkish furniture retailers show their influence on tastes through their descriptions of the 'Turkish taste in Vienna'. The most significant description of the majority of Turkish people in Vienna is taşralı (rural, provincial) with taşralı taste; taşralı also implies villager, peasant, traditional, old-fashioned, ignorant, bumpkin.

In one of its contemporary usages in Turkey, taşralı refers to a cultural form and taste that emerged with the internal migration from villages to the big cities beginning in the 1980s. Furniture retailers in Vienna usually use it to describe a form of traditional villager taste, claiming that 'they sell taşrall furniture for taşralı people'. During my visits to the furniture shops, I was struck by the repeat descriptions of Turkish taste in Vienna as 'taşralı' by all the entrepreneurs, managers and salespersons I interviewed. 'Taşralı furniture' (see Figure 8) is in fact an expression invented as a part of the Turkish vocabulary in Vienna. For example, the shop manager of Bender Mobilya, who is also a partner 


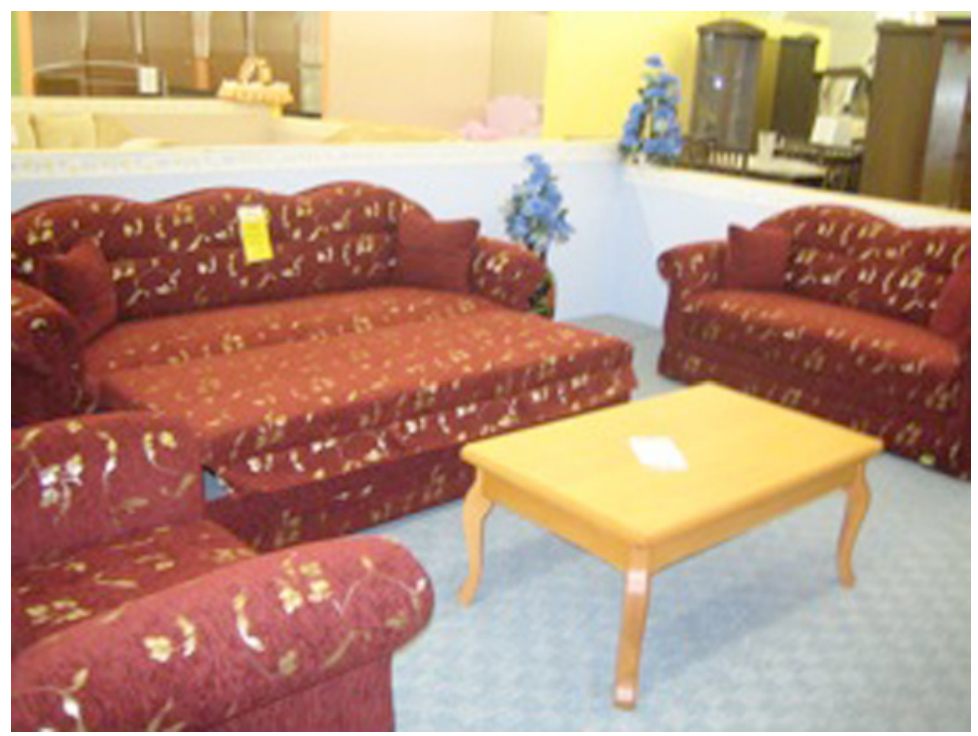

Figure 8. An example of 'ta囚ralı furniture' (Etsan Mobilya).

in the company, describes Turkish people in Vienna and their tastes as 'rural, conservative, backward, closed-minded and unchanging'. He feels that they preserve the taste they had when leaving Turkey 30 or 40 years ago, and explains these traits by the fact that the Turkish population in Vienna is dominated by migrants from central Anatolia, especially Yozgat, which he sees as a conservative city. But he also adds that they resist change, unlike their counterparts who remained in Yozgat and who have become 'more modern and open-minded'.

Furniture retailers thus claim that Turkish people in Vienna are caught in a taste culture of a certain space and time that existed prior to migration. Some of my informants partly agreed with this claim; they stated they often feel geri kalmış (behind the times) compared to their friends and relatives in Turkey. For example, young girls feel disappointed with the impact of their dress in Turkey and complain about their inability to keep up with the faster fashion changes in Turkey. Struggling for recognition as EuroTurks or Europeans in Turkey, they are instead seen as outdated, therefore 'less modern' than their counterparts in Turkey. It has been noted that various migrant groups see their lives and styles as behind the times compared to the country of origin (Ger and Østergaard, 1998; Jackson, 2004; Walton-Roberts and Pratt, 2005).

Furniture retailers continually emphasize that taşralı taste is specific to Turkish people in Vienna and contrast it with tastes in Turkey, which they view as 'modern'. These differing tastes materialize in two opposing furniture styles: 'taşralı' and 'modern' (see Figure 9). Retailers would often tell me that Turkish furniture sold in Vienna is no longer in demand in Turkey and that they would be selling totally different furniture if they opened a shop in Turkey. For example, Bender Mobilya, the only retailer with shops in Turkey as well as Vienna, sells markedly different furniture styles in each country, and 


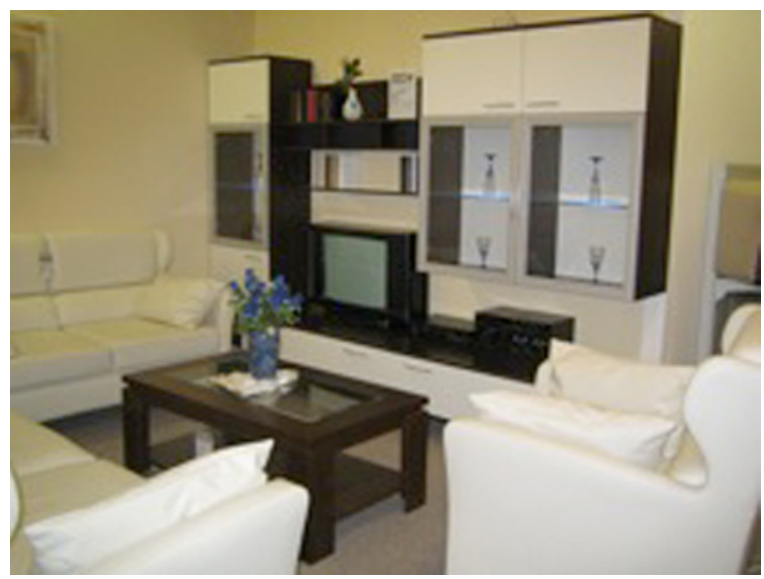

Figure 9. An example of 'modern' furniture (Evim Mobilya).

its shop manager admits that the company shifts furniture that cannot be sold in Turkey to Vienna. Retailers further claim a similarity between the tastes of Austrian customers and tastes in Turkey, identifying the 'Turkish taste in Vienna' as totally different. Powerfully pointing to the local particularity of this taste culture, these accounts also complicate the issue of the formation of a diasporic taste, which is often explained by taken-for-granted concepts of mixture and blending of distinct cultural elements.

Challenging the traditional views of cultural identity as fixed, bounded and rooted, global, transnational and certainly diasporic identities are increasingly addressed through various concepts that can be summed up as hybridization. The diasporic aesthetic, which is usually examined through the artistic and literary works of diasporas, is at the forefront of an emphasis on cross-overs, cultural mixes, blends and translations (Gilroy, 1987, 1993; Hall, 1991, 1992a, 1992b; Hill, 1999; Mercer, 1988; Werbner, 2000). In migratory and diasporic contexts, another sphere of aesthetics - the visual and material cultures of the everyday - is equally explained by a range of concepts that imply hybridization. It is both observed and advocated that diasporic material cultures are formed by fusions, mixtures and blends of distinct cultural and material forms in the domains of fashion, home decoration and consumption spaces (e.g. Beverly-McCloud, 1996; Bridgwood, 1999; Ger and Østergaard, 1998; Koskennurmi-Sivonen et al., 2004; Mehta and Belk, 1991; Oswald, 1999; Salih, 2002).

My critique of these studies does not intend to disprove or undervalue the hybrid forms and practices observed but rather to point out how they fail to raise questions over the particularities of the material cultures examined. Firstly, these studies comfortably apply a specific concept of hybrid aesthetic, arising from analysing one particular aesthetic realm constituted by literary and artistic products, to another aesthetic realm constituted by everyday material objects. Besides oversimplifying the concept of hybridity by reducing it to a simple process of mixing and blending, these studies regard diasporic material cultures as a fusion of distinct objects regardless of whether they are practised and expressed in a museum, a home, a body, or a shop. Secondly, the majority of such 
studies are caught up within the concept of 'two cultures', i.e. the culture of the country of settlement and the culture of the country of origin (see also Çăglar, 1997b). Therefore, they are dominated by an ahistorical, ungrounded and abstract concept of culture that erases the multiplicity and complexity of sites to which any diasporic cultural form is subjected and which allows understanding of a cultural particularity only in the sense of cultural mixing. Moreover, the idea that diasporic material cultures are formed through deploying and blending two sets of material and cultural domains limits material objects to one definite cultural setting where they are supposed to have fixed and stable meanings. Examining a diasporic taste necessitates an ethnographically informed and historically grounded analysis of which specific cultural, aesthetic and material domains are engaged with and how. In this study, I am concerned with the question of what kind of displacements, recontextualizations and inventions underlie the constitution of a diasporic material culture.

As mentioned, 'taşralı furniture' was initially introduced and marketed as 'truly Turkish' by Hane Mobilya, which was the first Turkish furniture shop in Vienna, opened in 1999. Other retailers attribute the shaping of taşrall taste to Hane Mobilya and state that they had to follow it. Most furniture sold by Hane Mobilya is produced by Bender Mobilya, a family-run furniture manufacturer and retailer, which was founded in Yozgat, Turkey, in 1997 and opened a shop in Vienna in 2005. Strikingly, Bender Mobilya was founded with the aim of manufacturing furniture only for Turkish people migrating to Western Europe. It has designed and manufactured furniture based on its observations on 'how Turkish people in Europe live and what they want'. From the outset, 'taşralı furniture' has been designed, manufactured and sold as a specific form of furniture targeted exclusively at Turkish customers in Europe.

The claimed conservatism of Turkish taste in Vienna is partly true in the sense that there is a tendency to regard changes and variations in taste as a sign of assimilation and a denial of 'essential' cultural values. In some cases of displacement, the desire for authenticity and the wish to reproduce or reinvent traditions are feasible strategies for belonging (Al-Ali and Koser, 2002; Kondo, 1996). Hence, to be caught in a taste that is associated with the past is a viable strategy, coinciding very well with the attempt to preserve or recover the past. However, despite its association with the past by the retailers, taşrall furniture does not exist in pre-migratory biographies in villages. Taşralı furniture (in other words, the 'beautiful Turkish furniture') that entered the market in Vienna in 1999 is the first furniture that was bought with the aim of decorating beautiful and tasteful homes.

Contrary to the retailers' assertions, it is not 'backward, closed-minded and traditional' attitudes that shape Turkish taste in Vienna, but social, historical and economic experiences of displacement and dwelling. Firstly, Turkish people in Vienna can be considered as migrants to the forms and spaces of urban consumer culture as they are mostly from rural origins in Turkey and have long avoided consuming in Vienna due to the myth of return. Turkish shops often describe the results of this recent entrance to urban consumption as 'not knowing what to buy' and 'a lack of taste'. Secondly, closely related to the guest worker experiences of Vienna, Turkish people tend to maintain the habits of poverty, although their actual poverty has largely vanished. Furniture retailers emphasize that since their customers have no criteria other than price and are indeed 'obsessed with 
price', they import cheaper, outmoded and poor-quality furniture instead of well-known, expensive brands from Turkey. Thirdly, some physical constraints on aesthetic choices, such as the small size of apartments in Vienna, make taşrall furniture more suitable than other kinds. Retailers explain that extended Turkish families living in small apartments prefer sofa-beds in dark colours that are less prone to show stains and dirt, and it is therefore risky for them to import fashionable living room furniture from Turkey that is lighter-coloured and designed for larger spaces.

Consequently, the Turkish furniture market in Vienna is dominated by a particular style, which is characterized - in Turkey - as cheap, poor quality and outmoded. The socalled taşrall taste is dominant not so much because it is the most widespread, but mainly because it is highlighted by retailers in accordance with their marketing strategies. Evim Mobilya, distinguishing itself from other retailers, states that it is the only one that also sells 'modern Turkish furniture' and describes its position as risky and courageous. Those of my informants who distance themselves from taşrall taste but who still want to be involved in a taste world labelled as Turkish often complained that their aesthetic preferences are ignored. The Turkish retail community in Vienna cannot (or does not) address the existing diversity and variety of tastes. While retailers complain that they have no option but to sell taşrall furniture, some Turkish customers criticize them for using 'lack of taste' and 'obsession with price' as an excuse for importing the cheapest goods to ensure more profit. A salesperson in Etsan Mobilya also noted that goods sold in Turkish shops in Vienna are those that are impossible to sell in Turkey, but stated a different reason for this. She feels that 'Argus-eyed [giant with 100 eyes] and grifter [sharp] traders in Turkey sell goods to the relatively more naïve Turkish entrepreneurs in Europe that they are unable to sell to businesses in Turkey.'

Such distinct business practices of Turkish retailers in Vienna often result in endowing a material object with a surprising, newfound fashionability. For example, a type of coffee table on casters, with adjustable height and covered with a ceramic surface, has become very popular in Vienna, despite being largely unknown in Turkey (see Figure 10). It is one of the best examples of taşrall furniture and a key piece in the repertoire of Turkish objects in Vienna. As noted by Çağlar (2002), the ceramic coffee table is also a familiar object in Turkish homes in Germany. Comparing the coffee tables used by the German-Turkish in their homes in Germany and in Turkey, Çağlar observes that while ceramic coffee tables are used in Germany for their practicality, more decorative coffee tables are used in Turkey as part of the struggle to attain a higher social status. She does not consider, however, how the ceramic coffee table became a significant object in those Turkish homes in Germany.

Ceramic coffee tables used to be produced only by a few small manufacturers around Zonguldak, a northern Anatolian town. They are rarely seen in Turkey, a fact that causes Çağlar (2002) to assert that they are not sold in Turkey. They were introduced in Austria, Germany and France by Bender Mobilya, which considers them as the perfect furniture for Turkish people living in Europe because of their practicality and taşralı style. Indeed, Bender Mobilya started business in 1998 by buying the tables from a manufacturer in Zonguldak and selling them to shops in Western European cities. Later that year, it started to manufacture its own ceramic coffee tables. Today, Bender Mobilya sells the tables to Turkish furniture shops in France, Germany and Austria, in its own shop in 


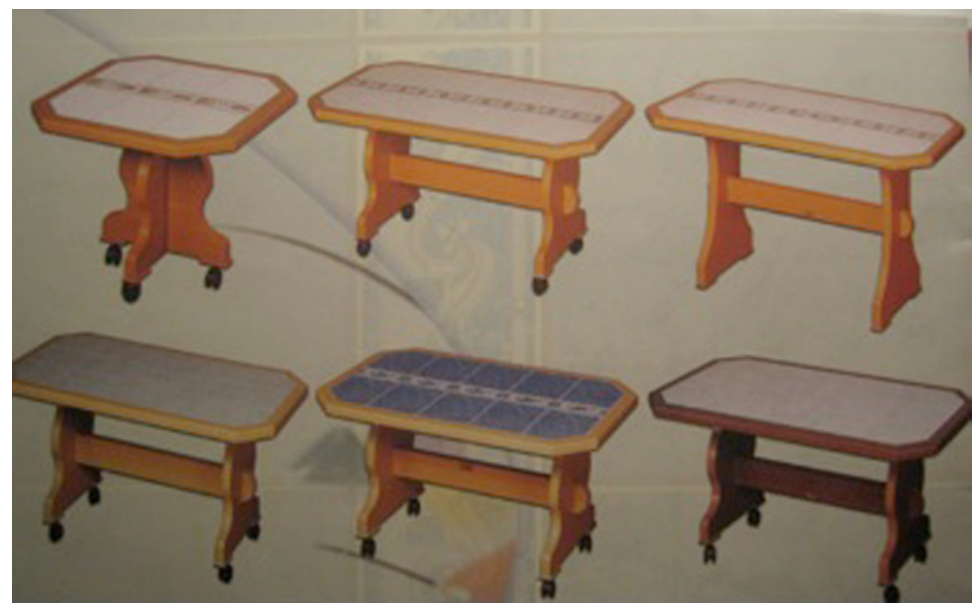

Figure 10. Ceramic coffee tables by Bender Mobilya, Source: Bender Mobilya catalogue.

Vienna, as well as in its shops in central and east Anatolia. The manager of the Vienna shop stated that the company manufactures ceramic coffee tables mainly to sell to Turks in Europe since they are not in demand in Turkey. He explains that there are only a few models in their shops in rural Turkey, because 'only rarely somebody (usually from a village) likes it and buys it'. In Vienna, however, the shop sells approximately 200 such tables monthly. Although it is not popular in Turkey and does not belong either to a personally experienced or collectively imagined material culture of the pre-migration past, the ceramic coffee table is considered a 'truly Turkish' piece of furniture in 'typically Turkish homes' in Vienna, as it corresponds to the historical, social, economic and material Turkish experiences of Vienna.

Taşralı furniture has been appropriated in Vienna as a key object of a collective taste. Its value arises not only from the fact that it is produced in and has been transported from Turkey, but more significantly from its circulation and recontextualization in Vienna. Turkish furniture becomes a part of the everyday experience of Vienna, as buying new furniture from Turkish shops becomes a social experience, a topic of conversation when women organize communal shopping excursions, or as it becomes possible to order furniture seen in a soap opera on Turkish TV. Yet can we comfortably assume that any furniture style marketed in Vienna as 'Turkish furniture' would have been appreciated as such? In other words, although it was not part of personal biographies, does taşrall furniture not have any connection to social and economic positions of Turkish people in Vienna? Taşralı furniture implies a similar social standing in Turkey, although it is not called that: rural, conservative, lower-class and varoş (ghetto). It is associated with consumer groups in rural areas or the peripheries of big cities inhabited by domestic migrants. Although its value has been recontextualized in Vienna, taşralı furniture points to a taste that may be shared by those in similar social and economic positions in Turkey and, remarkably, by people who migrated from rural areas to urban spaces regardless of whether this happened on a domestic or international scale. 
Last but not least, Turkish people engage with material cultures in Vienna in their own unique (and limited) ways as the segregation in the city directs its inhabitants to different spaces of consumption and style. Turkish taste resonates with particular styles shared by other migrant and diasporic groups in Vienna as well as working-class Austrians. For instance, Turkish youth share leisure spaces, such as some shopping malls, with other migrant and working-class Austrian youngsters, who all avoid the 1st district (the central district of Vienna). Hence, they interact with particular forms and spaces of material culture and neglect those to which they feel they do not belong or from which they are excluded. It is important to note, however, that their taste collectivity did not simply result from negative experiences of exclusion, but is actively, positively defended as the site of belonging.

Turkish people relate to tastes, styles and consumption spaces in Vienna and in Turkey in culturally, socially, economically and historically specific ways. It is in this respect that I argue for the complexities and particularities of the diasporic aesthetics of the everyday, which yield a taste that moves beyond both essentialist views and hybridization accounts. Cook and Crang (1996) use the concept of displacement as an alternative to metaphors of cultural creolization and hybridity because it does not rest on the idea of bounded and 'pure' cultures to mix. In accordance, I regard taşrall furniture both as objects placed within the Turkish experience of Vienna and as displaced objects, 'inhabiting many times and spaces which, far from being neatly bounded, bleed into and indeed mutually constitute each other' (Cook and Crang, 1996: 132-133). Taşralı taste is an 'invented tradition' (Hobsbawm and Ranger, 1983), constituted from within specific spaces of material culture that have been shaped by objects displaced and relocated by consumers, retailers and producers.

\section{Conclusion}

Taste diaspora is a form of belonging to Vienna as Turkish, which is achieved through a collective taste shaped within specific processes and paths of displacement and dwelling of both people and objects. As a specific diasporic sphere, which has been constituted and enunciated by practices and discourses around forms and spaces of material culture, it reveals how Turkishness, migrancy, diasporicity and foreignness or localness are lived out and transformed through taste in everyday objects. It is shaped by biographies of migration and resettlement, particular experiences of Vienna and Turkey, and locally articulated relations of production, retail and consumption.

Far from having some 'ethnic' associations or 'authentic' meanings, the repertoire of Turkish objects in Vienna has been created and made meaningful within the Turkish experience of Vienna. These displaced and relocated objects have been reappropriated as Turkish belongings because their biographies intertwine with the biographies of migration and resettlement. The decision to migrate might arise from the aspiration for Mercedes cars and gifts made in Europe that arrive at the village; feeling at home in Vienna might become possible by obtaining tea glasses from Turkey; the decision to permanently settle in Vienna might be fostered by mass migration of objects from Turkey; the sense of making and controlling spaces in Vienna might be achieved by the establishment of Turkish shops; the idea of a collective 'we' might be shaped by similar 
home decorations and clothing styles. The repertoire of Turkish objects in Vienna enables the objectification of communal narratives of migration and dwelling, and the achievement of a collective sense of belonging.

The 'Turkish taste in Vienna' is not a self-evident inherited cultural form existing prior to migration. Neither is it a simple blending of two taste cultures that supposedly belong to the country of origin and to the country of settlement. It has been shaped by particular processes and paths of production, retail and consumption and is implicated in various cultural, social, historical and economic particularities of the Turkish experience of Vienna. The economic purpose of migration and the long-lasting myth of return caused people to view their lives in Vienna as temporary and to develop a custom of poverty. Migrancy into urban forms of consumption generated a (perceived) 'lack of taste'. Diaspora entrepreneurs' explicit description of what the Turkish taste is have created a particular dominant taste culture and their careful elimination of outsider tastes in accordance with the marketing strategies has yielded a 'taste pocket'. At the same time, being caught in a taste that is associated with the past has served as a feasible strategy of belonging because of the desire for authenticity and the wish to reproduce traditions. Conformity to that taste serves as a performance and expression of Turkishness, owing to the efforts of imagining a collective 'we' and of embodying it in the visual and material everyday. Segregation in the city and the attachment to special social and economic positions result in limited and specific paths of engagement with spaces of style and consumption. And surely, the production and retail of specific objects that exclusively target Turkish people who migrated to Western European countries have powerfully contributed to that particular and distinct material culture.

\section{Acknowledgements}

I would like to express my sincere thanks to Alison J Clarke who supervised my doctoral research, from which this article derived. I am indebted to all my informants who voluntarily and sincerely participated in this study. Thanks are also due to the two anonymous referees for their insightful comments on this article.

\section{Funding}

This research received no specific grant from any funding agency in the public, commercial, or not-for-profit sectors.

\section{Notes}

1. Labour migration from Turkey to Austria started with the bilateral labour recruitment contract signed on 15 May 1964. Today, migrants and their descendants residing in Austria, with either Turkish or Austrian citizenship, number around 200,000. Following Germany, France and the Netherlands, Austria accommodated the fourth largest group of Turkish migrants generally in Western Europe. About 40 per cent of the country's Turkish population has settled in Vienna due to opportunities offered by industry and chain migration through ethnic networking.

2. There are differences between people who migrated as guest workers and those who migrated as students or ex-pats; between Turkish and Kurdish ethnic identifications and between Sunni and Alevi religious identifications. However, rejecting a pre-given and self-evident category of community, identity or culture, this study is not an attempt to define different focus groups 
and to reflect on or compare them. It follows a repertoire of objects in Vienna and certain individuals and groups that have become relevant to that repertoire, aiming to understand the active constitution of identities within the aesthetic of the everyday. It is also important to note that the majority of my informants in this study have Turkish and Sunni backgrounds; either they or their parents migrated to Vienna as guest workers. Throughout this article, 'Turkish' refers to people who migrated from Turkey and to their descendants who were born and/or grew up in Vienna. In this, my wording follows the practice of my informants, who deliberately referred to themselves as Turkish.

3. Several other factors have been influential in transforming attitudes towards consumption as well as in promoting the decision to permanently settle in Vienna. Firstly, an economically more secure life (e.g. because access to unemployment subsidy and health insurance) has lessened the importance of saving money for the future. Secondly, previous investments in Turkey have failed to generate expected profits.

4. In addition to 'Klein-Istanbul' and 'küçük İstanbul', Brunnenviertel is called 'küçük Yozgat' by Turkish people who do not identify themselves with the 'typical Turkish community in Vienna'. Yozgat is a small town in central Anatolia from where chain migration to Vienna was the most common.

\section{References}

Aksoy A and Robins K (2000) Thinking across spaces: Transnational television from Turkey. European Journal of Cultural Studies 3(3): 345-367.

Al-Ali N and Koser K (2002) Transnationalism, international migration and home. In: Al-Ali $\mathrm{N}$, Koser K (eds) New Approaches to Migration? Transnational Communities and the Transformation of Home. London: Routledge, 1-15.

Anwar M (1979) The Myth of Return: Pakistanis in Britain. London: Heinemann.

Appadurai A (1988) Introduction: Commodities and the politics of value. In: Appadurai A (ed.)

The Social Life of Things: Commodities in Cultural Perspective. Cambridge: Cambridge University Press, 3-63.

Auslander L (1996) Taste and Power: Furnishing Modern France. Berkeley: University of California Press.

Auslander L (2001) 'National taste?' Citizenship law, state form, and everyday aesthetics in modern France and Germany, 1920-1940. In: Hilton M, Daunton MJ (eds) The Politics of Consumption: Material Culture and Citizenship in Europe and America. Oxford: Berg, 109-129.

Baumann G (1996) Contesting Culture: Discourses of Identity in Multi-Ethnic London. Cambridge: Cambridge University Press.

Belk RW (1992) Moving possessions: An analysis based on personal documents from the 18471869 Mormon migration. Journal of Consumer Research 19: 339-361.

Bell V (1999) Performativity and belonging: An introduction. Theory, Culture \& Society 16(2): $1-10$.

Berger J (1975) A Seventh Man. Harmondsworth: Penguin.

Beverly-McCloud A (1996) 'This is a Muslim home': Signs of difference in the African-American row house. In: Metcalf BD (ed.) Making Muslim Space in North America and Europe. Berkeley: University of California Press, 65-74.

Bourdieu P (1977) Outline of a Theory of Practice (Cambridge Studies in Social and Cultural Anthropology). Cambridge: Cambridge University Press.

Bourdieu P (1984) Distinction: A Social Critique of the Judgement of Taste. London: Routledge. Bridgwood A (1999) Dancing the jar: Girls' dress at Turkish Cypriot weddings, In: Eicher JB (ed.) Dress and Ethnicity: Change across Space and Time. Oxford: Berg, 29-52. 
Çağlar A (1995) Mcdoner: Doner kebab and the social positioning struggle of German Turks. In: Costa JA, Bamossy GJ (eds) Marketing in a Multicultural World. London: Sage, 209-230.

Çağlar A (1997a) Go go dog and German Turks' demand for pet dogs. Journal of Material Culture 2(1): 77-94.

Çağlar A (1997b) Hyphenated identities and limits of 'culture'. In: Modood T, Werbner P (eds) The Politics of Multiculturalism in the New Europe: Racism, Identity and Community. London: Zed Books, 169-185.

Çağlar A (2002) Iki Elde Bir Sehpa. In: Kandiyoti D, Saktanber A (eds) Kültür Fragmanları: Türkiye'de Günlük Hayat. Istanbul: Metis Yayinlari, 293-307.

Chambers I (1994) Migrancy, Culture, Identity. London: Routledge.

Clifford J (1994) Diasporas. Cultural Anthropology 9(3): 302-338.

Clifford J (1997) Routes: Travel and Translation in the Late Twentieth Century. Cambridge, MA: Harvard University Press.

Cook I and Crang P (1996) The world on a plate: Culinary culture, displacement and geographical knowledges. Journal of Material Culture 1(2): 131-153.

D’Alisera J (2001) I Islam: Popular religious commodities, sites of inscription, and transnational Sierra Leonean identity. Journal of Material Culture 6(1): 91-110.

Edensor T (2002) National Identity, Popular Culture and Everyday Life. London: Berg.

Ehrkamp P (2005) Placing identities: Transnational practices and local attachments of Turkish immigrants in Germany. Journal of Ethnic and Migration Studies 31(2): 345-364.

Fischer S and McGowan M (1996) From 'Pappkoffer' to pluralism: On the development of migrant writing in the Federal Republic of Germany. In: Horrocks D, Kolinsky E (eds) Turkish Culture in German Society Today. Oxford: Berghahn, 1-22.

Fortier A-M (2000) Migrant Belongings: Memory, Space, Identity. Oxford: Berg.

Foster R (1999) The commercial construction of 'new nations'. Journal of Material Culture 4(3): 263-282.

Frölich M (1997) Reinventions of Turkey: Emine Sevgi Özdamar's Life is a Caravanserai. In: Jankowsky KH, Love C (eds) Other Germanies: Questioning Identity in Women's Literature and Art. New York: SUNY Press, 56-74.

Geismar H and Horst HA (2004) Materializing ethnography. Journal of Material Culture 9(1): $5-10$.

Ger G and Østergaard P (1998) Constructing immigrant identities in consumption: Appearance among Turko-Danes. Advances in Consumer Research 25: 48-52.

Gilroy P (1987) 'There Ain't No Black in the Union Jack': The Cultural Politics of Race and Nation. Chicago: University of Chicago Press.

Gilroy P (1993) The Black Atlantic: Modernity and Double Consciousness. London: Verso.

Gupta A and Ferguson J (1992) Beyond 'culture': Space, identity and the politics of difference. Cultural Anthropology 7(1): 6-23.

Hall S (1991) The local and the global: Globalization and ethnicity. In: King AD (ed.) Globalization and the World System. London: Macmillan, 19-40.

Hall S (1992a) The question of cultural identity. In: Hall S et al. (eds) Modernity and Its Futures. Cambridge: Polity Press, 274-325.

Hall S (1992b) New ethnicities. In: Donald J, Rattansi A (eds) 'Race', Culture and Difference. London: Sage, 252-260.

Hill J (1999) British Cinema in the 1980s: Issues and Themes. Oxford: Clarendon Press.

Hobsbawm E and Ranger T (eds) (1983) The Invention of Tradition. Cambridge: Cambridge University Press.

Horrocks D (1996) In search of a lost past: A reading of Emine Sevgi Özdamar's novel Das Leben ist eine Karawanserei, hat zwei Türen, aus einer kam ich rein, aus der anderen ging ich 
raus. In: Horrocks D, Kolinsky E (eds) Turkish Culture in German Society Today. Oxford: Berghahn Books, 23-45.

Jackson P (2004) Local consumption cultures in a globalizing world. Transactions of the Institute of British Geographers 29: 165-178.

Kaya A (2000) Berlin'deki Küçük İstanbul: Diyasporada Kimliğin Oluşumu. Istanbul: Büke Yayınları.

Kaya A (2002) Aesthetics of diaspora: Contemporary minstrels in Turkish Berlin. Journal of Ethnic and Migration Studies 28(1): 43-62.

Kondo D (1996) The narrative production of home, community, and political identity in Asian American Theater. In: Lavie S, Swedenburg T (eds) Displacement, Diaspora and Geographies of Identity. Durham, NC: Duke University Press, 97-118.

Kopytoff I (1988) The cultural biography of things: Commoditization as process. In: Appadurai A (ed.) The Social Life of Things: Commodities in Cultural Perspective. Cambridge: Cambridge University Press, 64-91.

Koskennurmi-Sivonen R, Koivula J and Maijala S (2004) United fashions: Making a Muslim appearance in Finland. Fashion Theory 8(4): 443-460.

Kosnick K (2004) Good guys and bad guys: Turkish migrants broadcasting in Berlin. In: Faist T, Özveren E (eds) Transnational Social Spaces: Agents, Networks and Institutions. Aldershot: Ashgate, 189-209.

Levi P (1987[1958]) If This Is a Man. London: Abacus, Sphere Books.

Mandel R (1990) Shifting centres and emergent identities: Turkey and Germany in the lives of Turkish Gastarbeiter. In: Eickelman DF, Piscatori J (eds) Muslim Travellers: Pilgrimage, Migration, and the Religious Imagination. London: Routledge, 153-171.

Mandel R (1996) A place of their own: Contesting spaces and defining places in Berlin's migrant community. In: Metcalf BD (ed.) Making Muslim Space in North America and Europe. Berkeley: University of California Press, 333-356.

Martin B and Mohanty CT (1986) Feminist politics: What's home got to do with it? In: De Lauretis T (ed.) Feminist Studies/Critical Studies. Bloomington: Indiana University Press, 191-211.

Mehta R and Belk R (1991) Artefacts, identity and transition: Favourite possessions of Indians and Indian immigrants to the United States. Journal of Consumer Research 17: 398-411.

Mercer K (ed.) (1988) Black Film, British Cinema. London: ICA.

Miller D (1987) Material Culture and Mass Consumption. Oxford: Basil Blackwell.

Oswald LR (1999) Culture swapping: Consumption and the ethnogenesis of middle-class Haitian immigrants. Journal of Consumer Research 25: 303-318.

Parkin DJ (1999) Mementoes as transitional objects in human displacement. Journal of Material Culture 4(3): 303-320.

Pratt MB (1984) Identity: Skin, blood, heart. In: Bulkin E et al. (eds) Yours in Struggle: Three Feminist Perspectives on Anti-Semitism and Racism. Brooklyn: Long Haul Press, 11-63.

Rapport N and Dawson A (1998) Home and movement: A polemic. In: Rapport N, Dawson A (eds) Migrants of Identity: Perceptions of Home in a World of Movement. Oxford: Berg, 19-38.

Safran W (1991) Diasporas in modern societies: Myths of homeland and return. Diaspora 1(1): 83-99.

Said EW (1980) The text, the world, the critic. In: Harari JV (ed.) Textual Strategies: Perspectives in Post-Structuralist Criticism. London: Routledge, 161-188.

Salih R (2002) Shifting meanings of home: Consumption and identity in Moroccan women's transnational practices between Italy and Morocco. In: Al-Ali N, Koser K (eds) New Approaches to Migration? Transnational Communities and the Transformation of Home. London: Routledge, 51-67. 
Savaş Ö (2008) Taste diaspora: The aesthetic and material practice of belonging. Unpublished doctoral thesis, University of Applied Arts, Vienna.

Savaş Ö (2010) The collective Turkish home in Vienna: Aesthetic narratives of migration and belonging. Home Cultures 7(3): 313-340.

Savaş Ö (2012) The 'Muslim' crying boy in Turkey: Aestheticization and politicization of suffering in Islamic imagination. In: Gruber C, Haugbolle S (eds) Rhetoric of the Image: Visual Culture in Modern Middle East. Bloomington: Indiana University Press, 103-126.

Tilley C (2006) Objectification. In: Tilley C et al. (eds) Handbook of Material Culture. London: Sage, 60-73.

Tolia-Kelly D (2004) Locating processes of identification: Studying the precipitates of re-memory through artefacts in the British Asian home. Transactions of the Institute of British Geographers NS 29: $314-329$.

Tölölyan K (1996) Rethinking diaspora(s): Stateless power in the transnational moment. Diaspora 5(1): 3-34.

Walsh K (2006) British expatriate belongings: Mobile homes and transnational homing. Home Cultures 3: 123-144.

Walton-Roberts M and Pratt G (2005) Mobile modernities: One South Asian family negotiates immigration, gender and class in Canada. Gender, Place and Culture 12(2): 173-195.

Werbner P (2000) Introduction: The materiality of diaspora - between aesthetic and politics. Diaspora 9(1): 5-20.

Werbner P (2002) The place which is diaspora: Citizenship, religion and gender in the making of chaordic transnationalism. Journal of Ethnic and Migration Studies 28(1): 119-133.

Werbner P (2004) Theorising complex diasporas: Purity and hybridity in the South Asian public sphere in Britain. Journal of Ethnic and Migration Studies 30(5): 895-911.

Westwood S (1995) Gendering diaspora: Space, politics, and South Asian masculinities in Britain. In: Van Der Veer P (ed.) Nation and Migration: The Politics of Space in the South Asian Diaspora. Philadelphia: University of Philadelphia Press.

White JB (1997) Turks in the new Germany. American Anthropologist 99(4): 754-769.

Wilk RR (1997) A critique of desire: Distaste and dislike in consumer behaviour. Consumption, Markets and Culture 1(2): 175-196.

\section{Author biography}

Özlem Savaş is Assistant Professor in the Department of Communication and Design at Bilkent University, Ankara. Her research interests focus on material and visual culture. Her recent publications include 'The collective Turkish home in Vienna: Aesthetic narratives of migration and belonging' (2010: Home Cultures 7(3): 313-340) and 'The 'Muslim' crying boy in Turkey: Aestheticization and politicization of suffering in Islamic imagination (in Gruber and Haugbolle, eds, Rhetoric of the Image: Visual Culture in the Modern Middle East, Indiana University Press, 2012). 